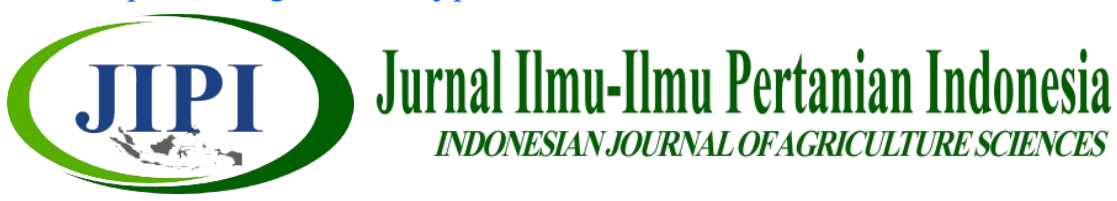

\title{
TAKARAN DOSIS LUMPUR SAWIT DAN PUPUK KCI TERHADAP PERTUMBUHAN DAN HASIL TANAMAN JAGUNG (Zea mays L) PADA ULTISOLS DI BENGKULU
}

\author{
B. W. Simanihuruk ${ }^{1}$, Yanti Oktavia Lumbantoruan ${ }^{1,}$ Herry Gusmara $^{2 *}$ \\ ${ }^{1}$ Program Studi Agroekoteknologi, Fakultas Pertanian Universitas Bengkulu \\ ${ }^{2}$ Program Studi Ilmu Tanah, Fakultas Pertanian Universitas Bengkulu \\ * Corresponding Author: herrygusmara@unib.ac.id
}

\begin{abstract}
[MEASURE DOSE OF PALM OIL SLUDGE AND KCl FERTILIZER TO THE GROWTH AND YIELD OF CORN (Zea mays L) ON ULTISOLS IN BENGKULU]. This study aims to determine the optimum dosage of palm oil sludge and $\mathrm{KCl}$ fertilizer to the growth and yield of corn on Ultisols. The research was conducted from June to October 2018. The design used is a randomized completely block design (RCBD) which is arranged factorial with two treatment factors. The first factor is the dosage of palm oil sludge which consists of 3 levels, i.e. 0 , 10 , and 20 tons/ha. The second factor is the dose of $\mathrm{KCl}$ fertilizer which consists of 3 levels, i.e. 0,100 , and $200 \mathrm{~kg} / \mathrm{ha}$. The results showed that there was no significant interaction between the application of palm oil sludge and $\mathrm{KCl}$ fertilizer on the growth and yield of corn. The application of palm oil sludge as much as 10 tonnes/ha tended to be the best against all observed growth and yield variables, with the highest plant height $11.35 \mathrm{~cm}$, the number of leaves 12.27 , leaf area $17.60 \mathrm{~cm}^{2}$, ear length $18.68 \mathrm{~cm}$, ear diameter $4.78 \mathrm{~cm}$, the weight of cobs/plot is $14.98 \mathrm{~g}$, the number of seeds/cobs is 20.17 , the weight of 100 grains is $5.68 \mathrm{~g}$, the weight of fresh crop is $14.26 \mathrm{~g}$, and the weight of dry crop is $8.91 \mathrm{~g}$. The application of $\mathrm{KCl}$ fertilizer had no significant effect on all observed growth and yield variables of corn.
\end{abstract}

Keyword: corn, palm oil sludge, $\mathrm{KCl}$

\begin{abstract}
ABSTRAK
Penelitian ini bertujuan menentukan dosis lumpur sawit dan dosis pupuk $\mathrm{KCl}$ yang optimum terhadap pertumbuhan dan hasil tanaman jagung. Penelitian dilaksanakan dari bulan Juni sampai dengan Oktober 2018. Rancangan yang digunakan adalah Rancangan Acak Kelompok Lengkap (RAKL) yang disusun secara faktorial dengan dua faktor perlakuan. Faktor Pertama adalah dosis lumpur sawit yang terdiri atas 3 taraf yaitu 0, 10, dan 20 ton/ha. Faktor kedua adalah dosis pupuk $\mathrm{KCl}$ yang terdiri atas 3 taraf yaitu 0,100 , dan $200 \mathrm{~kg} / \mathrm{ha}$. Hasil penelitian menunjukkan tidak terdapat interaksi yang nyata antara pemberian lumpur sawit dan pupuk $\mathrm{KCl}$ terhadap pertumbuhan dan hasil tanaman jagung. Pemberian lumpur sawit sebanyak 10 ton/ha cenderung terbaik terhadap seluruh variabel pertumbuhan dan hasil yang diamati, dengan tinggi tanaman tertinggi $11,35 \mathrm{~cm}$, jumlah daun 12,27 , luas daun $17,60 \mathrm{~cm}^{2}$, panjang tongkol 18,68 cm, diameter tongkol 4,78 cm, bobot tongkol/petak 14,98 g, jumlah biji/tongkol 20,17 butir, bobot 100 butir pipilan jagung 5,68 g, bobot brangkas segar 14,26 g, dan bobot brangkas kering 8,91 g. Pemberian pupuk $\mathrm{KCl}$ berpengaruh tidak nyata pada seluruh variabel pertumbuhan dan hasil tanaman jagung yang diamati.
\end{abstract}

Kata kunci: jagung, lumpur sawit, $\mathrm{KCl}$ 


\section{PENDAHULUAN}

Jagung (Zea mays L.) merupakan salah satu tanaman pangan penting di Indonesia dan sangat banyak digunakan untuk pakan ternak, bahan utama industri makanan, minuman, dan farmasi. Kandungan nutrisi jagung memiliki banyak manfaat yaitu sebagai sumber karbohidrat, asam lemak esensial, mineral, beta karoten, dan nutrisi lainnya yang dibutuhkan oleh tubuh manusia (Suarni \&Yasin, 2011). Setiap $100 \mathrm{~g}$ jagung mengandung kalsium $45 \mathrm{mg}$, fosfor $24 \mathrm{mg}$, besi $3 \mathrm{mg}$, kalium $78 \mathrm{mg}$, dan sodium $11 \mathrm{mg}$ (Suarni \& Widowati, 2009). Kebutuhan jagung sebagai bahan baku industri dan pakan ternak terus mengalami peningkatan dari tahun ke tahunnya. Produksi jagung dalam negeri belum mampu memenuhi kebutuhan tersebut secara keseluruhan sehingga pemerintah tetap melakukan impor (Ridwan, 2000). Produksi jagung tahun 2015 sebesar 19,61 juta ton pipilan kering naik sebesar $0,62 \%$ dibandingkan produksi jagung pada tahun 2014 yaitu sebesar 19,01 juta ton pipilan kering. Namun, perkiraan kebutuhan jagung untuk konsumsi dan industri secara nasional mencapai 22 juta ton pipilan kering. Oleh karena itu, Indonesia masih mengimpor jagung sebesar 3-3,5 juta ton (Badan Pusat Statistik, 2015).

Jumlah penduduk Indonesia sebesar 252,20 juta jiwa dengan laju pertumbuhan 1,38\% (Badan Pusat Statistik, 2015). Peningkatan jumlah penduduk berakibat pada semakin meningkat kebutuhan sandang, pangan, dan papan. Dari sisi papan berdampak semakin bertambahnya pemukiman penduduk dan berkurangnya lahan pertanian. Untuk mengatasi hal tersebut, perlu perluasan areal lahan pertanian melalui ekstensifikasi yaitu dengan cara memanfaatkan lahan marjinal salah satunya adalah Ultisol.

Ultisol merupakan jenis tanah yang terbentuk oleh proses pedogenesis yang menyerupai pembentukan tanah podsol (Indrihastuti, 2004). Ultisol mempunyai sifat peka terhadap erosi, perkolasi dan infiltrasi yang rendah, $\mathrm{pH}$ tanah yang rendah, kandungan $\mathrm{Al}$ yang tinggi, kandungan bahan organik yang rendah, serta ketersediaan unsur hara bagi tanaman rendah (Harjoso, 2002). Usaha untuk meningkatkan produktivitas Ultisol sebagai lahan pertanian dapat dilakukan dengan menggunakan bahan organik (Sutedjo, 1995). Bahan organik dapat meningkatkan dan memperbaiki sifat kimia, biologi, dan fisika tanah. Salah satu sumber bahan organik yang dapat meningkatkan dan memperbaiki lahan marjinal adalah lumpur sawit (Syukur, 2005).

Lumpur sawit merupakan limbah buangan yang dihasilkan selama proses pemerasan dan ekstraksi minyak. Kandungan unsur hara yang berasal dari lumpur sawit sekitar $0,4 \% \mathrm{~N}, 0,029-0,5 \% \mathrm{P}_{2} \mathrm{O}_{5}$, dan $0,15-0,2 \%$ $\mathrm{K}_{2} \mathrm{O}$ (Astianto, 2012). Bobot kering lumpur sawit hasil proses pengolahan limbah cair sebesar $24,2-68 \mathrm{~kg} / \mathrm{m}^{3}$ dengan kandungan bahan organik sebanyak $6,3 \mathrm{~kg} / \mathrm{m}^{3}$. Rasio C/N-nya relatif rendah yaitu 5 (Wahyono et al.,
2008). Hasil penelitian Mukri (2009) menyimpulkan bahwa pemberian lumpur sawit pada tanaman jagung berpengaruh nyata terhadap parameter tinggi tanaman, total luas daun, umur berbunga, umur panen, jumlah baris/tongkol, diameter tongkol, panjang tongkol, dan bobot tongkol dengan perlakuan terbaik $3,0 \mathrm{~kg} / \mathrm{plot}$. Hal ini sesuai dengan Hasil penelitian Nugroho et al. (2016) bahwa pemberian $150 \mathrm{~kg} / \mathrm{ha}$ NPK mutiara + 20 ton/ha lumpur sawit memberikan pertumbuhan dan hasil terbaik pada variabel tinggi tanaman, biomassa bagian atas kering, bobot 100 biji, dan bobot pipilan kering tanaman jagung.

Bahan lain yang digunakan untuk meningkatkan produksi jagung adalah pemberian pupuk majemuk NPK. Hara N, P, dan K merupakan hara esensial bagi tanaman. Pemberian $\mathrm{N}$ di dalam tanah secara langsung dapat meningkatkan kadar protein dan produksi tanaman jagung. Namun, pemenuhan unsur $\mathrm{N}$ saja tanpa $\mathrm{P}$ dan $\mathrm{K}$ akan menyebabkan tanaman mudah rebah, peka terhadap serangan hama penyakit, dan menurunnya kualitas produksi (Ahmed et.al., 2017). Beberapa penelitian menunjukkan bahwa pemberian bahan organik dan pemberian pupuk sintetik dapat meningkatkan $\mathrm{pH}$ tanah, $\mathrm{N}$-total, P-tersedia, dan K-tersedia di dalam tanah, dan meningkatkan produksi tanaman jagung (Abdurachman \& Sutono, 1998).

Salah satu unsur hara makro yang sangat diperlukan adalah K. Unsur K berfungsi sebagai pembentuk gula dan pati, translokasi gula, aktivitas enzim dan pergerakan stomata. Peningkatan bobot dan kandungan gula pada tongkol dapat dilakukan dengan cara mengefisienkan fotosintesis pada tanaman dan meningkatkan translokasi fotosintat ke bagian tongkol. Selain itu, unsur K juga mempunyai peranan dalam mengatur tata air di dalam sel dan transfer kation melewati membran (Setyono, 1986). Kalium dalam tanah sering ditemui sebagai faktor pembatas, $\mathrm{K}$ merupakan unsur hara yang mobil dan sangat peka terhadap pencucian terutama di daerah tropik yang memiliki curah hujan tinggi (Sarif, 1995). Pemberian pupuk KCl meningkatkan tinggi tanaman, bobot kering akar, dan bobot kering tajuk tanaman jagung (Sebayang et al., 2015).

Penelitian ini bertujuan untuk menentukan dosis optimum lumpur sawit dan pupuk $\mathrm{KCl}$ terhadap pertumbuhan dan hasil jagung.

\section{METODE PENELITIAN}

Penelitian ini dilaksanakan dari bulan Juni sampai Oktober 2018 di Bengkulu pada jenis tanah Ultisol dengan ketinggian tempat $10 \mathrm{~m}$ dpl. Bahan yang digunakan pada penelitian ini adalah benih jagung varietas Pertiwi, furadan $3 \mathrm{G}$, ajir, air, lumpur sawit, pestisida, pupuk urea, SP-36, KCl, dolomit, dan plastik label. Alat yang digunakan pada penelitian ini adalah sabit, ember, cangkul, meteran, timbangan digital, jangka sorong merek Vernier Calipers tiga ring $(150 \times 0,05 \mathrm{~mm})$, cutter, oven, chlorophyll meter, kamera, parang, gembor, tali rafia, terpal, handsprayer, alat tulis, dan kalkulator, 
serta peralatan lain yang mendukung pelaksanaan penelitian ini.

Rancangan yang digunakan adalah Rancangan Acak Kelompok Lengkap (RAKL) yang disusun secara faktorial dengan dua faktor perlakuan. Faktor Pertama adalah dosis lumpur sawit (L) yang terdiri atas 3 taraf yaitu: nol $\left(\mathrm{L}_{0}\right), 10\left(\mathrm{~L}_{1}\right)$, dan 20 ton/ha $\left(\mathrm{L}_{2}\right)$. Faktor kedua adalah dosis pupuk $\mathrm{KCl}(\mathrm{K})$ yang terdiri dari 3 taraf yaitu: nol $\left(\mathrm{K}_{0}\right), 100\left(\mathrm{~K}_{1}\right)$, dan 200 $\mathrm{kg} / \mathrm{ha}\left(\mathrm{K}_{2}\right)$.Dari dua faktor tersebut diperoleh 9 kombinasi perlakuan, setiap kombinasi perlakuan diulang sebanyak 3 kali, sehingga diperoleh 27 satuan percobaan.

Tahap awal penelitian diawali dengan melakukan analisis tanah. Tanah yang dianalisis diambil dengan cara mencangkul sedalam $20 \mathrm{~cm}$ secara diagonal dari 5 titik yang berbeda, sehingga dapat mewakili kondisi seluruh lahan pertanaman. Tanah dari setiap titik diambil sebanyak $0,5 \mathrm{~kg}$ dan dicampurkan ke dalam ember lalu diaduk sampai homogen. Tanah yang telah diaduk kemudian diambil sebanyak $0,5 \mathrm{~kg}$ dan dibawa ke Laboratorium Ilmu Tanah untuk dianalisis kandungan $\mathrm{N}, \mathrm{P}, \mathrm{K}, \mathrm{pH}, \% \mathrm{C}$-organik, dan KTK.

Persiapan lahan dilakukan dengan membersihkan lahan dari gulma dan sisa tanaman dengan menggunakan sabit. Pengolahan tanah dilakukan sebanyak dua kali. Olah tanah pertama dilakukan pada tiga minggu sebelum tanam. Olah tanah kedua dilakukan pada saat satu minggu sebelum tanam dengan menggemburkan tanah. Selanjutnya lahan yang telah diolah, dibuat petakan sebanyak 27 petakan dengan ukuran 2,8 $\mathrm{m}$ x 3,2 $\mathrm{m}$ dengan jarak tanam $70 \mathrm{~cm} \times$ $40 \mathrm{~cm}$. Jarak antar petak $0,5 \mathrm{~m}$ dan jarak antar ulangan $1 \mathrm{~m}$.

Dolomit diberikan sebanyak 2 ton/ha (Minardi, 2006) dua minggu sebelum tanam dengan cara ditabur merata pada seluruh permukaan tanah yang telah diolah pertama. Dolomit dan tanah pucuk (topsoil) dicampur merata. Sedangkan lumpur sawit diberikan satu minggu sebelum tanam. Lumpur sawit diaplikasikan secara merata di permukaan petakan sesuai dosis perlakuan, kemudian dicampur secara merata dengan lapisan olah tanah menggunakan cangkul.

Pupuk dasar diberikan pada saat tanaman jagung memiliki 3-4 plumula (daun lembaga). Pupuk dasar yang digunakan adalah Urea $300 \mathrm{~kg} / \mathrm{ha}$ dan SP-36 $150 \mathrm{~kg} / \mathrm{ha}$ (Muyassir, 2013). Pupuk urea diberikan tiga kali yaitu pada saat tanam $100 \mathrm{~kg} / \mathrm{ha}$ bersamaan dengan SP-36 sebanyak $150 \mathrm{~kg} / \mathrm{ha}$ dan pemberian pupuk $\mathrm{KCl}$ sesuai dengan perlakuan. Pemberian Urea yang kedua dilakukan pada 3 (tiga) minggu setelah tanam (MST) sebanyak $100 \mathrm{~kg} / \mathrm{ha}$ dan pemberian yang terakhir pada 6 MST sebanyak $100 \mathrm{~kg} / \mathrm{ha}$. Pupuk dasar diberikan dengan cara dilarikkan di samping baris tanaman dengan jarak \pm $10 \mathrm{~cm}$.

Benih jagung ditanam dengan sistem tanam benih langsung (tabela) dengan dengan cara menugal tanah pada kedalaman $\pm 3 \mathrm{~cm}$, jarak tanam $70 \mathrm{~cm} \mathrm{x}$ $40 \mathrm{~cm}$ (Mattobi, 2004). Benih jagung ditanam sebanyak
2 benih/lubang tanam disertai Furadan 3 G sebanyak 6 butir, lubang tanam ditutup kembali dengan tanah. Penjarangan tanaman dilakukan setelah tanaman berumur 14 HST dengan memilih satu tanaman jagung yang pertumbuhannya baik dan seragam. Penjarangan dilakukan dengan memotong tanaman yang pertumbuhan nya kurang optimal menggunakan cutter sehingga hanya menyisakan satu tanaman.

Tanaman sampel dipilih secara acak pada setiap petak percobaan dan bukan tanaman pinggir. Tanaman sampel dipilih sebanyak $20 \%$ dari total populasi tiap unit percobaan. sehingga diperoleh 6 tanaman/petak. Dengan demikian, terdapat 162 sampel tanaman. Enam tanaman sampel yang dipilih akan digunakan untuk pengukuran pada fase vegetatif maupun generatif tanaman jagung.

Pemeliharaan yang dilakukan meliputi pengairan, pembumbunan, dan penyiangan yang dilakukan secara teratur dan berkala. Panen dilakukan berdasarkan kriteria panen jagung dengan ciri-ciri rambut jagung mengalami perubahan warna menjadi coklat, tongkol jagung telah terisi penuh, biji kering, keras dan mengkilat, serta apabila ditekan dengan ibu jari tidak membekas (Cahyono, 2007).

Variabel pertumbuhan dan hasil yang diamati meliputi tinggi tanaman $(\mathrm{cm})$, diameter batang $(\mathrm{cm})$, jumlah daun, tingkat kehijauan daun diukur pada saat fase vegetatif akhir yang ditandai dengan dimulainya pertumbuhan dan perkembangan tongkol dan tandan bunga jantan yang sudah mulai terbentuk, luas daun $\left(\mathrm{cm}^{2}\right)$ atas dasar Susilo (2015), bobot tongkol tanpa kelobot $(\mathrm{g})$, panjang tongkol tanpa kelobot $(\mathrm{cm})$, diameter tongkol tanpa kelobot $(\mathrm{cm})$, bobot segar tanaman (g), bobot kering tanaman (g), bobot 100 butir (g), jumlah biji/tongkol, dan bobot hasil pipilan/ tongkol $(\mathrm{g})$.

Data yang dikumpulkan dianalisis menggunakan analisis varian (ANOVA) pada taraf 5\%. Peubah yang menunjukkan kebermaknaan pada analisis varian dilanjutkan dengan PO (polynomial orthogonal).

\section{HASIL DAN PEMBAHASAN}

Lahan penelitian yang digunakan bekas pertanaman ubi kayu yang telah diberakan oleh pemiliknya selam tiga bulan lebih dan ditumbuhi berbagai jenis gulma berdaun lebar. Hasil analisis tanah lahan yang digunakan menunjukkan kandungan $\mathrm{pH}$ tanah 5,20 (masam), kandungan $\mathrm{N}$ total sebesar $0,22 \%$ (sedang), C-Organik sebesar 2,06\% (sedang), P-tersedia sebesar $5,56 \mathrm{ppm}$ (sedang), K-tersedia sebesar $0,15 \mathrm{me} / 100 \mathrm{~g}$ tanah (rendah), dan KTK tanah sebesar 27,75 Cmol $(+) / \mathrm{kg}$ tanah (sedang).

Data curah hujan pada bulan Juli rata-rata 11 $\mathrm{mm}$, Agustus $67 \mathrm{~mm}$, September $20 \mathrm{~mm}$, dan 0 pada bulan Oktober. Hal ini menunjukkan bahwa ketersediaan air selama periode pertumbuhan tanaman jagung belum 
memenuhi kebutuhan tanaman jagung. Kebutuhan total air tanaman jagung berkisar $700-800 \mathrm{~mm}$, pada fase vegetatif dibutuhkan air sebanyak $300 \mathrm{~mm}$ dan pada fase generatif sebanyak 400-500 mm (Muamar et al., 2012). Oleh karena itu, pengairan dilakukan semaksimal mungkin untuk memenuhi kebutuhan air tanaman.

Pertumbuhan dan hasil tanaman jagung dalam penelitian ini belum sesuai dengan deskripsi varietas Pertiwi-3 (9,64 ton/ha pipilan kering). Pada saat tanaman jagung berumur 3 MST, pertumbuhan sebagian besar tanaman jagung tidak normal dan kerdil. Hal ini diduga disebabkan oleh kondisi lingkungan yang tidak mendukung seperti terjadinya kemarau dan sumber air yang kurang mencukupi. Gulma yang tumbuh di lahan penelitian dikendalikan dengan disiangi pada 3 dan 6 MST. Panen jagung dilakukan pada umur 101 hari setelah tanam yang ditandai dengan rambut jagung yang berubah warna menjadi coklat, tongkol jagung telah terisi penuh, dan biji kering, keras.

Hasil penelitian menunjukkan bahwa tidak terjadi interaksi yang nyata antara pemberian lumpur sawit dan pupuk $\mathrm{KCl}$ terhadap semua variabel pertumbuhan dan hasil jagung yang diamati. Pemberian lumpur sawit sebagai faktor tunggal berpengaruh tidak nyata terhadap semua variabel pertumbuhan dan hasil yang diamati, kecuali pada diameter batang. Pupuk $\mathrm{KCl}$ sebagai faktor tunggal berpengaruh tidak nyata pada seluruh variabel yang diamati (Tabel 1).

Tabel 1. F-hitung pengaruh lumpur sawit dan pupuk $\mathrm{KCl}$ terhadap pertumbuhan dan hasil jagung

\begin{tabular}{|l|c|c|c|}
\hline \multirow{2}{*}{ Variabel } & \multicolumn{3}{|c|}{ F hit } \\
\cline { 2 - 4 } & $\begin{array}{c}\text { Lumpur } \\
\text { sawit }\end{array}$ & $\begin{array}{c}\text { Pupuk } \\
\text { KCl }\end{array}$ & Interaksi \\
\hline Tinggi tanaman & 1,741 & 0,271 & 0,793 \\
\hline Diameter batang & $21,273 *$ & 0,02 & 1,416 \\
\hline Jumlah daun & 1,541 & 0,463 & 0,721 \\
\hline Tingkat kehijauan daun & 1,004 & 0,17 & 0,58 \\
\hline Total luas daun & 0,589 & 0,189 & 0,731 \\
\hline Bobot tongkol & 2,032 & 0,44 & 0,947 \\
\hline Panjang tongkol & 1,873 & 0,503 & 1,193 \\
\hline Diameter tongkol & 1,891 & 0,303 & 1,196 \\
\hline Bobot pipilan/tongkol & 0,177 & 0,661 & 1,178 \\
\hline Jumlah biji/tongkol & 1,536 & 0,345 & 0,886 \\
\hline Bobot 100 butir & 1,605 & 0,506 & 0,836 \\
\hline Bobot berangkasan segar & 0,55 & 0,613 & 0,666 \\
\hline Bobot berangkasan kering & 0,379 & 1,224 & 0,925 \\
\hline Keterangan : * berpengaruh nyata pada taraf 5\% \\
\hline
\end{tabular}

Pemberian pupuk pada dosis terlalu tinggi dapat menyebabkan terhambatnya pertumbuhan dan perkembangan tanaman, sedangkan dosis yang terlalu rendah menyebabkan pemupukan tidak memberikan pengaruh terhadap hasil tanaman (Suriadikarta, 2005). Pemberian unsur hara makro maupun mikro dalam jumlah yang cukup dan seimbang, mampu meningkatkan nutrisi yang dibutuhkan tanaman (Indrasari\&Syukur, 2006). Pemupukan yang tidak memperhatikan saat aplikasi dan jenis pupuk yang digunakan sering tidak memberikan hasil yang memuaskan.

Tanaman yang cukup $\mathrm{K}$ dapat mempertahankan kandungan air dalam jaringannya sehingga petumbuhan dan hasil menjadi maksimal. Kandungan K-tersedia pada analisis tanah awal sebesar $0,15 \mathrm{me} / 100 \mathrm{~g}$ tanah yang tergolong rendah diduga tidak mampu memenuhi kebutuhan unsur hara $\mathrm{K}$ pada tanaman jagung. Keter -sediaan unsur hara dari lumpur sawit yang diberikan juga membutuhkan dekomposisi yang lebih lama. Bahan organik lumpur sawit memiliki efek residu dimana hara yang terkandung di dalamnya secara berangsur menjadi bebas dan tersedia bagi tanaman, bahkan efek residu ini masih berpengaruh 3-4 tahun setelah aplikasi (Hakim et al., 1986). Hal ini diduga yang menyebabkan tidak terjadinya interaksi lumpur sawit dan pupuk $\mathrm{KCl}$ pada pertumbuhan dan hasil jagung.

Pemberian $\mathrm{KCl}$ juga belum bisa memenuhi kebutuhan unsur hara $\mathrm{K}$ pada tanaman jagung. Hal ini di duga karena pupuk $\mathrm{KCl}$ memiliki sifat mobilitas dalam tanah dan mudah hilang karena pelindian. Besar atau kecilnya $\mathrm{K}$ yang diserap oleh tanaman sangat dipengaruhi oleh KTK (Wanarso, 2005). Tanah dengan KTK tinggi mempunyai kemampuan menyimpan dan menyediakan $\mathrm{K}$ lebih besar begitu sebaliknya, jika KTK tanah rendah maka kemampuan menyimpan dan menyediakan $\mathrm{K}$ juga rendah. Berdasarkan analisis tanah awal pada lahan yang digunakan, kandungan KTK nya sebesar $27,75 \mathrm{Cmol}(+) / \mathrm{kg}$ yang tergolong sedang diduga belum mampu menyimpan dan menyediakan $\mathrm{K}$ tersedia bagi tanaman.

Lumpur sawit memiliki potensi dalam meningkatkan kesuburan tanah karena memiliki bahan organik dan kandungan hara (Jenny \& Suwadji, 1999). Pemberian pupuk lumpur sawit berpengaruh nyata terhadap diameter batang tanaman jagung. Pola hubungan dosis lumpur sawit terhadap diameter batang tanaman jagung membentuk pola linier positif dengan persamaan $\mathrm{y}=2,0148+$ $0,0134 \mathrm{x}\left(\mathrm{R}^{2}=0,03\right)($ Gambar 1).

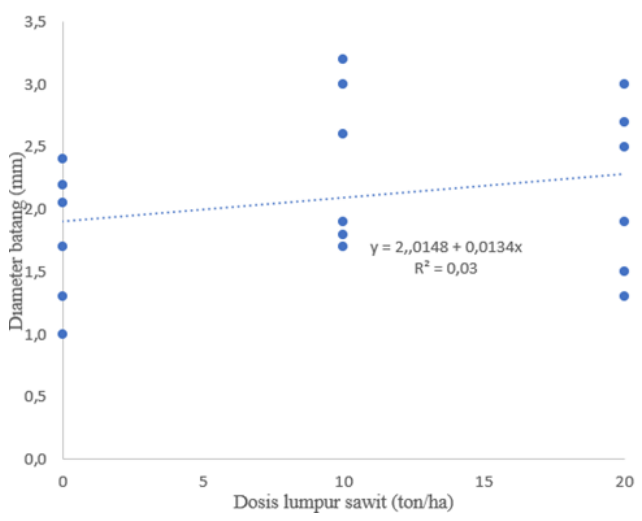

Gambar 1. Hubungan antara dosis lumput sawit dan diameter batang 
Hal ini berarti setiap penambahan satu satuan dosis lumpur sawit akan diiringi dengan peningkatan diameter batang tanaman jagung rata-rata sebesar $0,0134 \mathrm{~cm}$. Pemberian dosis lumpur sawit yang semakin tinggi mampu meningkatkan diameter batang tanaman jagung. Hal ini di duga karena lumpur sawit mampu meningkatkan kesuburan tanah dan menyediakan unsur hara untuk memenuhi kebutuhan tanaman jagung. Hasil penelitian Sari et al. (2017) menunjukkan bahwa pemberian lumpur sawit dengan dosis 30 ton/ha merupakan dosis terbaik dalam peningkatan ketersediaan unsur hara pada Ultisol.

Pertumbuhan vegetatif tanaman jagung adalah pertumbuhan yang berhubungan dengan penambahan ukuran dan jumlah sel pada suatu tanaman. Pertumbuhan tanaman jagung meliputi fase perkecambahan yang dilanjutkan dengan fase pertumbuhan vegetatif yang mencakup perbesaran batang. Lumpur sawit memiliki potensi dalam meningkatkan kesuburan tanah karena memiliki bahan organik dan kandungan hara. Menurut Soepardi (2000) bahan organik dapat memperbaiki struktur tanah akibat peningkatan porositas tanah, sehingga kemampuan tanah dalam mengikat air menjadi semakin meningkat. Wahyono et al. (2008) menyatakan bahwa lumpur sawit memiliki kandungan hara $\mathrm{N}$ $(27,03 \mathrm{~kg} /$ ton BK$), \mathrm{P}(2,54 \mathrm{~kg} / \mathrm{ton} \mathrm{BK}), \mathrm{K}(15,5 \mathrm{~kg} /$ ton $\mathrm{BK}), \mathrm{Ca}(14,20 \mathrm{~kg} /$ ton $\mathrm{BK})$, dan $\mathrm{Mg}(7,36 \mathrm{~kg} /$ ton $\mathrm{BK})$. Dengan kandungan unsur hara tersebut, diduga dosis lumpur sawit mampu menyediakan unsur hara pada pertumbuhan diameter batang, terutama unsur hara $\mathrm{N}$ yang berperan dalam meningkatkan vegetatif tanaman. Hal tersebut dapat dilihat dari adanya peningkatan diameter batang. Peningkatan tersebut menunjukkan perbedaan yang nyata, dan peningkatan pertumbuhan tanaman secara tidak langsung dipengaruhi pemberian lumpur sawit yang mengandung unsur hara yang dapat digunakan tanaman untuk bertumbuh dengan optimal. Jenny \& Suwadji (1999) menyatakan bahwa lumpur sawit mampu meningkatkan kesuburan tanah. Bersama dengan mineral tanah, bahan sludge yang diaplikasikan berpengaruh pada sejumlah aktivitas kimia tanah. Berdasarkan penelitian yang dilakukan Budianta (2004) pemberian limbah cair kelapa sawit mampu meningkatkan kandungan hara yang dibutuhkan oleh tanaman.

Pemberian lumpur sawit berpengaruh tidak nyata terhadap pertumbuhan dan hasil tanaman jagung kecuali terhadap diameter batang. Secara umum terlihat bahwa lumpur sawit sebanyak 10 ton/ha mampu menghasilkan pertumbuhan dan hasil tanaman jagung yang terbaik (Tabel 2). Hal tersebut diduga karena dosis lumpur sawit 10 ton/ha mampu memberikan keseimbangan unsur hara lebih baik dibandingkan dengan perlakuan lain, sehingga fotosintetis pada tanaman lebih baik.

Wahyono et al. (2008) menyatakan bahwa lumpur sawit memiliki kandungan hara N (27,03 kg/ton BK), P (2,54 kg/ton BK), K (15,5 kg/ton BK), Ca (14,20 kg/ ton $\mathrm{BK})$, dan $\mathrm{Mg}(7,36 \mathrm{~kg} /$ ton $\mathrm{BK})$. Unsur hara $\mathrm{N}$ pada tanaman berfungsi meningkatkan kadar zat hijau daun (Waskito et al., 2018). Apabila zat hijau daun meningkat maka fotosintesis akan semakin meningkat dan pertumbuhan tanaman semakin membaik

Pengamatan pertumbuhan dan hasil jagung pada penelitian ini masih di bawah kemampuan berproduksi. Tidak tercapainya pertumbuhan dan hasil sesuai deskripsi karena pada saat pertumbuhan terjadi kekeringan. Berdasarkan data curah hujan terlihat bahwa periode tanam jagung dilakukan pada musim kemarau dengan curah hujan pada bulan Juli sampai dengan Oktober sebesar $109 \mathrm{~mm}$ sehingga terjadi cekaman air. Lisar et al. (2012) menyatakan akibat cekaman kekeringan pada tanaman yaitu penutupan stomata, penurunan laju fotosintetis dan laju transpirasi, penurunan pemanjangan sel serta penghambatan pertumbuhan, dan juga mengganggu proses penyerbukan sehingga hasil produksi kurang maksimal.

Hasil analisis tanah awal menunjukkan bahwa tanah lokasi penelitian memiliki pH tanah 5,20, kandungan $\mathrm{N}$ total yaitu sebesar $0,22 \%$, kandungan $\mathrm{C}$ Organik yaitu sebesar 2,06\%, kandungan P-tersedia yaitu sebesar 5,56 ppm, kandungan K-tersedia yaitu sebesar $0,15 \mathrm{me} / 100 \mathrm{~g}$, dan KTK tanah yaitu sebesar 27,75 $\mathrm{Cmol}(+) / \mathrm{kg}$. Kandungan C-organik mempunyai peranan memperbaiki struktur tanah, memperbaiki aerasi tanah, menekan laju erosi, penyedia hara bagi tanaman, dan sumber energi bagi jasad renik. Kandungan C-organik diduga tidak bisa menyediakan kebutuhan hara tanaman. Hasil penelitian Pandapotan (2016) menunjukkan bahwa pemberian limbah lumpur sawit ber-pengaruh tidak nyata terhadap peningkatkan $\mathrm{N}$-total, $\mathrm{K}_{\mathrm{dd}}$, dan KTK tanah. Hasil penelitian Fachdarisman (2013) menunjukkan bahwa pemberian bahan organik blotong tebu $(\mathrm{C} / \mathrm{N}$ 26,62) dengan dosis $0,5,10$, dan 20 ton/ha memberikan

Tabel 2. Pengaruh perlakuan lumpur sawit terhadap variabel pertumbuhan dan hasil tanaman jagung

\begin{tabular}{|c|c|c|c|c|c|c|c|c|c|c|}
\hline $\begin{array}{c}\text { Lumpur sawit } \\
\text { (ton/ha) }\end{array}$ & $\begin{array}{c}\text { TT } \\
(\mathrm{cm})\end{array}$ & $\begin{array}{c}\text { JD } \\
(\text { helai })\end{array}$ & $\begin{array}{c}\text { LD } \\
\left(\mathrm{cm}^{2}\right)\end{array}$ & $\begin{array}{c}\text { PT } \\
(\mathrm{cm})\end{array}$ & $\begin{array}{c}\text { DT } \\
(\mathrm{cm})\end{array}$ & $\begin{array}{c}\text { BTT } \\
(\mathrm{g})\end{array}$ & $\begin{array}{c}\text { JBT } \\
(\text { biji) }\end{array}$ & $\begin{array}{c}\text { Bobot 100 biji } \\
(\mathrm{g})\end{array}$ & $\begin{array}{c}\text { BBS } \\
(\mathrm{g})\end{array}$ & $\begin{array}{c}\text { BBK } \\
(\mathrm{g})\end{array}$ \\
\hline 0 & 10,04 & 10,72 & 16,2 & 17,15 & 4,6 & 13,16 & 18,1 & 5,46 & 12,92 & 8,3 \\
\hline 10 & 11,35 & 12,27 & 17,6 & 18,68 & 4,78 & 14,98 & 20,17 & 5,68 & 14,26 & 8,91 \\
\hline 20 & 10,28 & 11,51 & 16,95 & 17,18 & 4,47 & 11,11 & 18,84 & 5,63 & 13,06 & 8,88 \\
\hline
\end{tabular}

Keterangan : TT : tinggi tanaman; JD : jumlah daun; LD : luas daun; PT : panjang tongkol; DT : diameter tongkol BTT : bobot tongkol/tanaman; JBT : jumlah biji/tongkol; BBS : bobot brangkasan segar; BBK :bobot brangkasan kering 
pengaruh tidak nyata terhadap tinggi tanaman, total luas daun, indeks luas daun, umur berbunga, panjang tongkol, diameter tongkol, jumlah biji/tongkol, bobot tongkol segar/batang, bobot tongkol berkelobot/plot, bobot tongkol tanpa kelobot/plot, dan bobot tongkol/ha.

Ketersediaan hara dari pupuk organik yang diberikan lebih lambat dan membutuhkan waktu dekomposisi yang lebih lama, sehingga belum bisa memenuhi kebutuhan hara tanaman jagung. Hasil penelitian Siagian et al. (2018) menunjukkan bahwa waktu pemberian lumpur sawit 15 ton/ha pada 0 , 2, dan 4 minggu setelah tanam memberikan pengaruh tidak nyata pada semua variabel vegetatif dan generatif yang diamati pada tanaman jagung manis. Bahan organik ini memiliki efek residu hara yang terkandung di dalamnya secara berangsur menjadi bebas dan tersedia bagi tanaman, bahkan efek residu ini masih berpengaruh 3 sampai 4 tahun setelah aplikasi (Hakim \& Sediyarsa, 1986). Hasil penelitian Sutriadi et al. (2005) menun-jukkan bahwa aplikasi bahan organik sebesar 2 ton/ha dapat meningkatkan produksi jagung sebanyak $6 \%$ pada musim pertama, sedangkan pada musim kedua mampu meningkatkan produksi jagung sebesar $40 \%$ pada perlakuan kontrol maupun dengan bahan organik. Hal ini menunjukkan bahwa dampak pemberian bahan organik baru terlihat pada musim tanam kedua.

Kalium merupakan unsur hara makro yang penting selain $\mathrm{N}$ dan $\mathrm{P}$ serta diserap tanaman dalam jumlah besar. Pemberian pupuk $\mathrm{KCl}$ pada penelitian ini memberikan hasil berpengaruh tidak nyata terhadap seluruh variabel yang diamati (Tabel 1). Hasil rata-rata pertumbuhan dan hasil tanaman jagung pada pemberian pupuk $\mathrm{KCl}$ disajikan pada Tabel 3.

Pemberian pupuk $\mathrm{KCl}$ sebesar $200 \mathrm{~kg} / \mathrm{ha}$ cenderung memberikan hasil terbaik terhadap variabel hasil tanaman jagung yaitu panjang tongkol, diameter tongkol, bobot tongkol/petak, jumlah biji/tongkol, dan bobot 100 biji (Tabel 3). Hal ini diduga karena kandungan unsur $\mathrm{K}$ yang rendah di lokasi penelitian yaitu $0,15 \mathrm{me} / 100 \mathrm{~g}$ serta ketersediaan air yang kurang mencukupi bagi kebutuhan tanaman jagung. Secara fisiologis, peranan $\mathrm{K}$ bagi tanaman yaitu membentuk daun mengangkut karbohidrat. Bilamana tanaman kekurangan $\mathrm{K}$, maka akan terjadi akumulasi karbohidrat yang berakibat menurunnya kadar pati dalam tanaman. Nurhayati (2006) menyatakan bahwa efektifitas pupuk $\mathrm{KCl}$ yang diberikan oleh petani bervariasi tergantung dari jenis tanah dan tanaman. Selain itu penelitian Sukarjo et al. (2017) pada tanaman padi menunjukkan bahwa penambahan $\mathrm{K}$ yang tinggi akan menyebabkan serapan $\mathrm{K}$ pada gabah makin tinggi tetapi tidak akan menambah produksi gabah. Hal ini menegaskan bahwa $\mathrm{K}$ merupakan unsur hara yang dikonsumsi secara mewah, namun dampaknya terhadap pertumbuhan dan hasil tidak signifikan.

Tingkat kemasaman tanah $(\mathrm{pH})$ yang optimal untuk pertumbuhan jagung berkisar 5,60 - 6,20 (Riwandi et al., 2014). Pada kondisi tanah dengan $\mathrm{pH}$ rendah ketersediaan K-nya akan sangat rendah. Ketersediaan unsur hara di dalam tanah sangat dipengaruhi oleh tingkat kemasaman tanah (Sarwono, 2003). Rendahnya ketersediaan K menyebabkan tanaman tidak dapat melakukan pertumbuhan dan perkembangan secara optimal.

Tanaman jagung membutuhkan jumlah air yang banyak dalam pertumbuhan dan perkembangannya. Data curah hujan di lokasi penelitian menunjukkan bahwa periode tanam jagung dilakukan pada musim kemarau dengan curah hujan total sebesar $109 \mathrm{~mm}$ sehingga terjadi cekaman air. Pengaruh ketersediaan air terhadap pertumbuhan tanaman sangat besar. Menurut Silahooy (2018) bahwa ketersediaan air dalam tanah mempengaruhi transportasi unsur hara tanah oleh akar tanaman. Jika ketersediaan air di dalam tanah menurun maka akan terjadi cekaman kekeringan sehingga pertumbuhan tidak normal. Badami \& Amzeri (2011) menyatakan bahwa kekurangan air pada jagung pipilan saat fase reproduktif menyebabkan penurunan jumlah biji, bobot kering biji, bobot kering batang, dan bobot kering akar.

Tabel 3. Pengaruh perlakuan pupuk $\mathrm{KCl}$ terhadap variabel pertumbuhan dan hasil tanaman

\begin{tabular}{|c|c|c|c|c|c|c|c|c|c|c|}
\hline Pupuk KCl & TT & JD & LD & PT & DT & BTT & JBT & Bobot 100 biji & BBS & BBK \\
\hline$(\mathrm{kg} / \mathrm{ha})$ & $(\mathrm{cm})$ & (helai) & $\left(\mathrm{cm}^{2}\right)$ & $(\mathrm{cm})$ & $(\mathrm{cm})$ & (g) & (biji) & (g) & (g) & (g) \\
\hline 0 & 10,71 & 11,92 & 17,22 & 17,7 & 4,68 & 13,7 & 18,8 & 5,55 & 12,93 & 8,4 \\
\hline 100 & 10,27 & 11,07 & 16,75 & 17,2 & 4,57 & 13,25 & 18,7 & 5,44 & 13,03 & 8,29 \\
\hline 200 & 10,69 & 11,51 & 17,07 & 18,1 & 4,6 & 14,23 & 19,6 & 5,59 & 14,3 & 9,4 \\
\hline
\end{tabular}

Keterangan : TT : tinggi tanaman; JD : jumlah daun; LD : luas daun; PT : panjang tongkol; DT : diameter tongkol

BTT : bobot tongkol/tanaman; JBT : jumlah biji/tongkol; BBS : bobot brangkasan segar; BBK :bobot brangkasan kering 


\section{KESIMPULAN}

Berdasarkan hasil penelitian ini,dapat disimpulkan bahwa tidak terdapat interaksi antara pemberian lumpur sawit dengan pupuk $\mathrm{KCl}$ terhadap pertumbuhan dan hasil jagung. Pemberian lumpur sawit sebanyak 10 ton/ha cenderung terbaik terhadap seluruh variabel pertumbuhan dan hasil yang diamati, dengan hasil tinggi tanaman $11,35 \mathrm{~cm}$, jumlah daun 12,27 , luas daun $17,60 \mathrm{~cm}$, panjang tongkol $18,68 \mathrm{~cm}$, diameter tongkol $4,78 \mathrm{~cm}$, bobot tongkol/petak 14,98 g, jumlah biji/ tongkol 20,17 butir, bobot 100 butir pipilan jagung $5,68 \mathrm{~g}$, bobot brangkas segar 14,26 g, dan bobot brangkas kering 8,91 g. Pemberian pupuk $\mathrm{KCl}$ memberikan pengaruh yang tidak nyata pada seluruh variabel pertumbuhan dan hasil tanaman jagung yang diamati.

\section{DAFTAR PUSTAKA}

Abdurachman, A. \& Sutono, S. (1998). Rehabilitasi lahan melalui pengelolaan bahan organik dan pemupukan. Prosiding Lokakarya Nasional Pembahasan Hasil Penelitian Pengelolaan Daerah Aliran Sungai. Sekretariat Tim Pengendali Bantuan Penghijauan dan Reboisasi Pusat. Pusat Penelitian Tanah dan Agroklimat, Bogor.

Ahmed, M., Rauf, M., Mukhtar, Z., \& Saeed, N.A. (2017). Excessive use of nitrogenous fertilizers: an unawareness causing serious threats to environment and human health. Environmental Science and Pollution Research, 24(35), 26983-26987.

Astianto, A. (2012). Pemberian berbagai dosis abu boiler pada pembibitan kelapa sawit (Elaesis guineensis jacq) di pembibitan utama (main nursery). Skripsi. Sarjana Fakultas Pertanian. Universitas Riau, Pekanbaru.

Badami, K. \& Amzeri, A. (2011). Identifikasi varian somaklonal toleran kekeringan pada populasi jagung hasil seleksi in vitro dengan PEG. Agrovigor. 4 (1), 7-13.

Balai Penelitian Tanah. (2005). Petunjuk Teknis Analisis Kimia Tanah, Pupuk, Tanaman, dan Air. Balai Penelitian Tanah, Bogor.

Badan Pusat Statistik. (2015). Peningkatan Produksi Jagung Nasional. http://bps.go.id. 09 Oktober 2017.

Badan Pusat Statistik. (2015). Laju Pertumbuhan Penduduk Menurut Provinsi. http://bps.go.id/ site/pilih data. 09 Oktober 2017.

Cahyono, B. (2007). Jagung; Tehnik Budidaya dan Analisis Usahatani. CV Aneka Ilmu, Semarang.

Fachdarisman, F. (2013). Takaran bahan organik blotong tebu terhadap pertumbuhan dan hasil tanaman jagung manis (Zea mays saccharata Sturt).
Skripsi. Program Studi Agroteknologi. Fakultas Pertanian. Universitas Taman Siswa, Padang.

Hakim, N., Nyakpa, M.Y., Lubis, A.M., Nugroho, S.G., Saul, M.R., Diha, M.A., \& Bailey, H. H. (1986). Dasar-dasar Ilmu Tanah. Universitas Lampung. Lampung.

Hakim, L. \& Sediyarsa, M. (1986). Percobaan perbandingan beberapa sumber pupuk fosfat alam di daerah Lampung Utara. hlm. 179-194. Dalam Kurnia, U., Dai, J. Suharta, N., Widjaya-Adhi, I.P.G., Adiningsih, S., Sukmana, S., Sumantri, J.P. (Ed.). Prosiding Pertemuan Teknis Penelitian Tanah, Cipayung, 10-13 November 1981. Pusat Penelitian Tanah, Bogor.

Harjoso, Y. (2002). Pengaruh pemberian pupuk organik dan nitrogen terhadap pertumbuhan dan hasil tanaman jagung manis. Mahasiswa Program Pasca sarjana, Universitas Brawijaya, Malang.

Indrasari, A., \& Syukur, A. (2006). Pengaruh pemberian pupuk kandang dan unsur hara mikro terhadap pertumbuhan jagung pada ultisol yang dikapur. Jurnal Ilmu Tanah dan Lingkungan, 6(2), 116 -123 .

Indrihastuti, D. (2004). Kandungan kalsium pada biomassa tanaman Acacia mangium Willd pada tanah podsolik merah kuning di hutan tanaman industri. Skripsi. Fakultas Kehutanan. Institut Pertanian Bogor, Bogor.

Jenny, M.U. \& Suwadji, E. (1999). Pemanfaatan Limbah Minyak Sawit (Sludge) sebagai Pupuk Tanaman dan Media Jamur Kayu.BATAN, Bogor.

Lisar, S.Y.S., Motafakkerazad, R., Hossain, M.M., \& Rahman, I.M.M. (2012) Water Stress in Plants: Causes, Effects and Responses. In Water Stress;Rahman, M., Hasegawa, H., Eds.; InTech: Rijeka, Croatia.

Mattobi. (2004). Pengaruh pemangkasan tassel dan jarak tanam pada pertumbuhan daun terhadap akumulasi bahan kering biji dan hasil tanaman jagung (Zea mays.L). Skripsi. Universitas Brawijaya, Malang,

Minardi. (2006). Optimalisasi pengelolaan lahan kering untuk pengembangan pertanian tanaman pangan_(daring). https://library.uns.ac.id. .22 Maret 2018

Muamar, Z.A., Triyono, T. \& Rosadi, B. (2012). Analisis neraca air tanaman jagung (Zea mays) di Bandar Lampung. Jurnal Teknik Pertanian Lampung. $1(1), 1-10$

Mukri, D. (2009). Pemberian lumpur sawit dan NPK organik terhadap pertumbuhan dan produksi tanaman jagung manis. Skripsi. Universitas Islam Riau, Pekanbaru.

Muyassir. (2013). Respon jagung tongkol ganda (Zea mays L.) terhadap pemupukan urea dan kompos. J. Manajemen Sumberdaya Lahan, 2 (3), 250-254. 
Nugroho, J.S., Gusmara, H. \& B.W. Simanihuruk. (2016). Pengaruh lumpur sawit dan NPK sintetik terhadap pertumbuhan dan hasil tanaman jagung. Agritrop Jurnal Ilmu-Ilmu Pertanian. 14(2), 114-119.

Nurhayati, N. (2006). Pertumbuhan dan hasil jagung manis pada berbagai waktu aplikasi bokashi limbah kulit buah kakao dan pupuk anorganik. J Agroland. 13(3), 256-259.

Pandapotan, C.D. (2016). Pemanfaatan limbah lumpur padat (sludge) pabrik pengolahan kelapa sawit sebagai alternatif penyediaan unsur hara di tanah ultisol. Jurnal Agroekoteknologi Universias Sumatera Utara. 5(2), 271-276.

Ridwan. (2000). Pengaruh bahan organik pada tanaman jagung di lahan alang-alang. Balai Pengkajian Teknologi Pertanian Sukarami, Jawa Barat.

Riwandi, R., Merakati, H., \& Hasanudin, H. (2014). Teknik Budidaya Jagung dengan Sistem Organik di Lahan Marjinal. Universitas Bengkulu, Bengkulu.

Sari, D. P., \& Gusmara, H. (2017). Pertumbuhan dan hasil jagung manis (Zea mays saccharata) dengan pengurangan pupuk NPK yang digantikan dengan lumpur kelapa sawit (sludge) pada tanah ultisol. Agritrop: Jurnal Ilmu-Ilmu Pertanian (Journal of Agricultural Science), 15(1), 138-150.

Sarif, S. (1995). Kesuburan dan Pemupukan Tanah Pertanian. Penerbit Pustaka Buana, Bandung.

Sarwono, H. (2003). Ilmu Tanah. Penerbit PT. Akademika Pressindo, Jakarta.

Sebayang, A.M., Damanik, M.M.B., \& Lubis, K.S. (2015). Aplikasi pupuk $\mathrm{KCl}$ dan pupuk kandang ayam terhadap ketersediaan dan serapan kalium serta pertumbuhan tanaman jagung (Zea mays L.) pada tanah inseptisol Kwala Bekala. Jurnal Online Agroekoteaknologi. 3(3), 870-875.

Setyono, S. (1986). Kesuburan Tanah dan Nutrisi Tanaman.Pendidikan Pasca Sarjana.KPK UGMUNIBRAW, Universitas Brawijaya, Malang.

Siagian, D.M., Simanihuruk, B.W. \& Gusmara, H. (2019). Waktu pemberian lumpur sawit dan dosis NPK pada pertumbuhan dan hasil jagung manis (Zea mays saccharata Sturt.) di ultisols. J. Ilmu-Ilmu Pertanian Indonesia. 21 (1), 27-31. DOI: https://doi.org/10.31186/ jipi.21.1.27-31.

Silahooy, C. (2018). Efek pupuk KCl dan SP-36 terhadap kalium tersedia, serapan kalium dan hasil kacang tanah (Arachis hypogaea L.) pada tanah Brunizem. Jurnal Agronomi Indonesia (Indonesian Journal of Agronomy), 36(2), 126 $-132$

Suarni \& Yasin, M. (2011). Jagung sebagai sumber pangan fungsional. Iptek Tanaman Pangan 6 (1), 41-56.

Suarni \& Widowati, S. (2009). Struktur, Komposisi dan Nutrisi Jagung. Balai Besar Penelitian Serealia. http://www.balitsereal.litbang.deptan.co. id. 14 Juli 2014.

Sukarjo, A. H., Hidayah, A., \& Zulaehah, I. (2017). Keseimbangan dan ketersediaan kalium dalam tanah dengan berbagai input pupuk pada sistem sawah tadah hujan. In Prosiding Seminar Nasional Tahunan FP UNS, 1(1), 317-321.

Suriadikarta, D.A. (2005). Teknologi Bahan Organik Tanah. In Teknologi Pengelolaan Lahan Kering. Badan Litbang Pertanian, Bogor.

Susilo, D.E.H. (2015). Identifikasi nilai konstanta bentuk daun untuk pengukuran luas daun metode panjang kali lebar pada tanaman hortikultura di tanah Gambut. Anterior Jurnal, 14(2),139146. DOI: https://doi.org/10.33084/anterior. v14i2. 178 .

Sutedjo. (1995). Pengaruh macam dan waktu pemberian pupuk nitrogen terhadap efisiensi pengambilan nitrogen oleh tanaman jagung. Media Penelitian Sukamandi. 9, 5-10

Sutriadi, M.T., Hidayat R., Rochayati, S. \& Setyorini, D. (2005). Ameliorasi lahan dengan fosfat alam untuk perbaikan kesuburan tanah kering masam Typic hapludox di Kalimantan Selatan. hlm 143-155 In Prosiding Seminar Nasional Inovasi Teknologi Sumber Daya Tanah dan Iklim. Buku II. Bogor, 14-15 September 2004. Pusat Penelitian dan Pengembangan Tanah dan Agroklimat, Bogor.

Syukur, A. (2005). Pengaruh pemberian bahan organik terhadap sifat sifat tanah dan pertumbuhan caisim di tanah pasir pantai. J. Ilmu Tanah dan Lingkungan. 5(1), 30 - 38.

Wahyono, S., Sahwan, F.L., Martono, J.H., \& Suyanto, F. (2008). Evaluasi teknologi penanganan limbah padat industri sawit. In Prosiding Seminar Teknologi Untuk Negeri, BPPT.

Waskito, K., Aini, N., \& Koesriharti, K. (2018). Pengaruh komposisi media tanam dan pupuk nitrogen terhadap pertumbuhan dan hasil tanaman terong (Solanum melongena L.). Jurnal Produksi Tanaman, 5(10), 1586-1593. 